\title{
Is the Direction of the Acupuncture Meridians Opposite in Males and Females at the Same Time of Day or Night?
}

\author{
Maria Kuman* \\ Holistic Research Institute, USA
}

Submission: February 15, 2018; Published: February 22, 2018

*Corresponding author: Maria Kuman, Holistic Research Institute, 1414 Barcelona Dr., Knoxville, TN 37923, Email: holisticare1@gmail.com

\section{Letter to Editor}

The ancient book on acupuncture [1] explains that the acupuncture meridians are like rivers, but instead of water energy runs along them. In the way the rivers flow into seas, the acupuncture meridians flow into six spinning energy seas. In Hindu books, the six spinning seas are called 'chakras', which in Sanskrit mean 'spinning wheels' [2]. They rule and regulate the six endocrinal glands in the body, which release hormones directly into the blood stream. In amount mg per litter blood, these hormones (and the chakras related to them) rule and regulate all the processes in the body.

The chakras are aligned along the backbone and they alternate: vortex (spinning clockwise like a tornado), anti-vortex (spinning counter-clockwise), then again a vortex, etc. Similar chains of alternating vortices and anti-vortices are observed on the surface of the Sun during solar activity. They are called solar spots and are observed in the equatorial area of the Sun. They are the opening of tornado-like vortices, which alternate with anti-vortices. If in the north hemisphere of the Sun they are vortex - anti-vortex -vortex, etc., in the southern hemisphere they are anti-vortex-vortex-anti-vortex, etc. [2,3]).

Thus, the spinning of the vortices and anti-vortices is in opposite direction in the northern and southern hemisphere of the Sun. Hindu books [2] also explain that the chakras in the human body spin in opposite direction in males and females at the same time of day or night. So, if you split the Sun along the equator, the vortex sequence of the southern hemisphere will correspond to that in the male body, while the vortex sequence of the northern hemisphere will correspond to that in the female body.

Hindu's Yoga books explain that the spinning of the chakras changes to opposite at dawn and dusk, but remain opposite in males and females. They say that the best way to balance chakras is at dawn and dusk when they change the direction of their spinning. So the rotation of the chakras is gender specific and it changes to the opposite twice a day: at dawn and at dusk [2].

If the acupuncture meridians are rivers with energy running along them, and they flow into six spinning energy seas [4], when the spinning of these seas (chakras) changes to opposite, one can expect the direction of the rivers that flow into them to change to the opposite, i.e. the direction of the acupuncture meridians to change to the opposite at dawn and dusk. Is it true?

\section{Help Verify the Ancient Wisdom}

Is everything we read in the ancient sources right? I have patented electronic equipment, which allows me to measure chakras, and the information is extremely valuable for diagnosis and treatment. I have found: chakra imbalance specific for sleepwalking, chakra imbalance specific for bipolar disorder, chakra imbalances specific for autism, etc.

I have also found a way to detect the spinning of each chakra in males and females, and I have the proof that they spin in opposite direction in males and females. Since the acupuncture meridians flow into and off the chakras, if the chakras spin in opposite direction in males and females, the acupuncture meridians need to run in opposite direction in males and females.

Is this the case? Is the direction of the acupuncture meridians different in males and females? The question remains open. I invite all practicing acupuncturists to help find the answer. Some sensitive individuals sense an electric impulse running from the treated acupuncture point in the direction of the meridian. Please, ask your male and female patients, if they can sense this electric impulse. Ask them in which direction they feel the impulse runs and record their answers. Thank you. And we will discuss the answers on the pages of the journal. 


\section{References}

1. Veith I, Ti H, Ching N, Wen S (1971) University of California Press, Berkley, Los Angeles, London.

2. Kuman M (2009) Yoga-health benefits, science, and wisdom. Health and Happiness Books.
3. Kuman M (2009) Find your soul mate-secrets of the soul. Health and Happiness Books.

4. Kuman M (2008) Modern aspects of ancient acupuncture. Health and Happiness Books. (C) Co This work is licensed under Creative

\section{Your next submission with Juniper Publishers} will reach you the below assets

- Quality Editorial service

- Swift Peer Review

- Reprints availability

- E-prints Service

- Manuscript Podcast for convenient understanding

- Global attainment for your research

- Manuscript accessibility in different formats ( Pdf, E-pub, Full Text, Audio)

- Unceasing customer service

Track the below URL for one-step submission https://juniperpublishers.com/online-submission.php 